\title{
Quantitative Evaluation of Karst Developmental Differences Based on Improved Analytic Hierarchy Process and Multidimensional Extension Matter Element Model
}

\author{
Xinyi Wang $\mathbb{D}^{1,2}$ Yu Zou, ${ }^{1}$ Qi Wang $\mathbb{D},{ }^{3}$ Xiaoman Liu, ${ }^{1}$ Pingqing Zhang, ${ }^{4}$ Jianlin Li, $^{1}$ \\ and Mengjie Yao ${ }^{1}$ \\ ${ }^{1}$ Institute of Resources \& Environment, Henan Polytechnic University, Jiaozuo 454000, China \\ ${ }^{2}$ Collaborative Innovation Center of Coalbed Methane and Shale Gas for Central Plains Economic Region, Jiaozuo, \\ Henan Province 454000, China \\ ${ }^{3}$ College of Geosciences and Engineering, North China University of Water Resources and Electric Power, Zhengzhou 450045, China \\ ${ }^{4}$ Pingdingshan Tianan Coal Co. Ltd., Pingdingshan 467000, China
}

Correspondence should be addressed to Qi Wang; wangqi@ncwu.edu.cn and Mengjie Yao; yaomengj@outlook.com

Received 24 June 2019; Revised 20 October 2019; Accepted 21 November 2019; Published 6 December 2019

Academic Editor: Maurizio Barbieri

Copyright (c) 2019 Xinyi Wang et al. This is an open access article distributed under the Creative Commons Attribution License, which permits unrestricted use, distribution, and reproduction in any medium, provided the original work is properly cited.

In this study, limestone solubility, rock thickness, burial depth, hydrodynamic cycle, and geological tectonic of mine No. 13 in the Pingdingshan coalfield (China) were selected to evaluate the degree of karst development. The weight of each index factor to the karst development was determined by using the improved analytic hierarchy process. The multidimensional extensional matter model was used to determine the degree of karst development of the four mining areas (named 1st to 4th) of the Pingdingshan mine No. 13. The results show that the degree of karst development differs zonally, with 1st and 2nd mining areas presenting the lowest degree of karst development (grade II-IV, for an average quantification value of 3.0) and 4th mining area having the highest degree (grade IV-V, for an average quantification value of 4.7). In the vertical direction, the development degree of the vertical layer $\mathrm{L}_{1}-\mathrm{L}_{4}$ karst in the Carboniferous Taiyuan Formation is grade IV-V, with an average quantitative value of 4.5, whereas the layers $\mathrm{L}_{5}-\mathrm{L}_{7}$ in the Taiyuan Formation had a III-V grade, with an average quantitative value of 3.75 , and the Cambrian limestone grade was II-IV, for an average quantitative value of 2.75 , i.e., the development degree of karst gradually decreases from shallow to deep.

\section{Introduction}

Carbonate karst usually refers to the dissolution of carbonate rocks caused by acidic fluids, resulting in a large number of holes, caves, and fractures. Because the geological structure, lithological characteristics, hydrodynamic cycling conditions, burial depth, and various other factors all present spatial differences, the development degree of karst varies according to the burial depth or the location along the (zonal) plane.

Many studies have investigated the characteristics and differences of the development of karst under water-rich and hydraulic conditions, as well as the factors responsible [1-5]. Sokolov [6] held that karst development is a geological process in which soluble rock is destroyed by dissolved water flow. It is mainly controlled by four conditions: rock solubility, rock permeability, groundwater mobility, and groundwater dissolution capacity. Legrand and Stringfield [7] studied the factors that affect the permeability of rock formations in karst areas, as well as briefly describe the developmental characteristics of karst, including the typical surface features such as sparse streams and bare rocks, as well as underground features comprising karst caves. In the 1960s and 1970s, the karst research group of the Institute of Geology of the Chinese Academy of Sciences elaborated on the lithology, dissolution mechanism, and the geological structure characteristics of the carbonate rock and the regional development characteristics of karst in China [8]. Ford and 
Williams and Fornós et al. $[9,10]$, respectively, delineated the influence of chemical characteristics, geological structure, climate, and other factors of lithologic karst water on karst development and karst development characteristics; these studies demonstrated that in addition to typical coastal karstification, meteoric water recharge and possibly deep recharge from hypogenic sources can affect the features of karst. Huang and Wang [11] investigated the recharge channel of a groundwater in a Karst mining area by using an environmental isotope method and found that the main recharge source in the north of Taihang Mountains is in a carbonateexposed area of China. Lancia et al. [12] conducted combined experiments and a hydrogeological evaluation method to determine the water-conducting characteristics of karstdeveloped rock masses; the limits of continuum modeling for karst media were addressed by combining two methods. Yao et al. [13] established a fully coupled antivelocity theoretical control model based on factors such as water flow, karst fissure erosion characteristics, and permeability change and used it to predict the karst water inrush time under different geological conditions; the results showed that the inverse velocity theory is capable of predicting the occurrence of water inrush under different conditions. Sauro et al. [14] conducted detailed statistics on the distribution and direction of karst development in southern Italy and analyzed the differences in karst development under different geological structures. Finally, we conclude that the development of the cave was strictly guided by a few favorable surfaces with stratigraphic and tectonic origins. Chen et al. [15] explained the spatial variability of Cambrian limestone karst development based on the solubility of rocks, water permeability, water chemistry, and water cycle characteristics of the Pingdingshan mining area in China. Chitsazan et al. [16] compared the karst development of the Kano anticline in Iran's Zagros Mountains with that of the Shotori Mountains in central Iran and proposed that the difference in their karst development was caused by the difference of the geological structure and rainfall. Zhou et al. [17] investigated the spatial and geographical patterns of 4960 karst caves in Guizhou of China and studied the influence and development of lithology, structure, climate, hydrology, and elevation on the distribution, quantity, and spatial pattern of the caves. Sun et al. [18] and Lipar and Webb [19] showed that the $\mathrm{CO}_{2}$ content has a great impact on the degree of karst development. The erosive capacity is stronger when the $\mathrm{CO}_{2}$ content is higher in a rock formation. The erosive capacity of $\mathrm{CO}_{2}$ is higher when it is coupled with the participation of groundwater. As the depth increases, the replenishment of $\mathrm{CO}_{2}$ in the water is insufficient, so the circulation of the groundwater is slowed down and the erosive capacity of $\mathrm{CO}_{2}$ is reduced. Thus, the development of karst in a coalfield eventually occurs via vertical zonation, where the development of the shallow karst becomes deeper and stronger. Li et al. [20, 21] studied the correlation between groundwater and the morphology of karst and established a model of the karst development degree using a hydrochemical kinetic-fractal index based on experimental corrosion data, thereby providing foundations for quantitative evaluations of the morphology and development of karst. Zhang et al. [22] selected six main factors that affect the development of karst as evaluation indexes and established an evaluation system for the underground karst development degree by combining the analytic hierarchy process with a Bayesian method. This method was then employed for the preliminary identification of the karst development status in railway tunnel engineering, thereby providing theoretical foundations to facilitate quantitative evaluations of the karst development degree.

As shown above, many research results on the characteristics and differences of karst development exist, but these mostly consist in qualitative description and chart comparisons. However, few quantitative analyses exist to evaluate the degree of karst development difference from multiple factors by using modern methods [23, 24]. That is, the quantitative identification of karst developmental differences based on comprehensive index thresholds merits further study. Therefore, the Carboniferous and Cambrian limestone strata of the Ji coal seam floor formation of the Pingdingshan coalfield mine No. 13 are further studied in this paper. The five following influencing factors are selected as index factors for characterizing karst development differences: limestone lithology, limestone thickness, burial depth, hydrodynamic cycle, and geological structure. A mathematical model for calculating the comprehensive index threshold and for identifying the degree of development of limestone karst in a certain spatial range is established by coupling an improved analytic hierarchy process and the multidimensional extension matter element model. The results of this study are expected to provide strong technical support for objectively and clearly discriminating the differences in karst development characteristics.

\section{Research Methods}

2.1. Improved Analytic Hierarchy Process. Determining the weight value of each index factor is the key to evaluate the degree of karst development, and the selection of the most appropriate methodology is crucial for ensuring the accuracy of the identification results. At present, the methods commonly used to determine weights are the analytic hierarchy process and the entropy weight method [25-27].

The analytic hierarchy process (AHP) is a practical multicriteria decision-making method. This method can express complex problems in an orderly hierarchical structure and can deal with qualitative and quantitative evaluation indicators in decision-making schemes. The improved AHP uses the three-scale method of the optimal transfer matrix to construct the judgment matrix and calculate the weight. Compared with the standard AHP, it can improve the accuracy and objectivity of the judgment results and greatly enhance the operability.

The comparison of the relative importance of selected indicators is the basis for constructing the judgment matrix in the improved AHP. If the former indicator is more important than the latter one, then it is assigned the value of 1 . If the former indicator is as important as the latter one, then 0 is taken, and if the latter indicator is more important than the previous one, the value -1 is assigned. The structural 
judgment matrix is constructed, and the weight of each evaluation index is finally determined [25].

Firstly, judgment matrix $A$ is constructed according to the importance of the influencing factors:

$$
A=\left[\begin{array}{cccc}
a_{11} & a_{12} & \cdots & a_{1 j} \\
a_{21} & a_{22} & \cdots & a_{2 j} \\
\cdots & \cdots & \cdots & \cdots \\
a_{i 1} & a_{i 2} & \cdots & a_{i j}
\end{array}\right]
$$

where $a_{i j}=1$ indicates that $i$ is more important than $j, a_{i j}=0$ means that $i$ and $j$ are equally important, and $a_{i j}=-1$ means that $j$ is more important than $i$.

Matrix $R$ is the optimal transfer matrix for matrix $A$, and the value of each element in matrix $R$ can be calculated by equation $r_{i j}=(1 / n) \sum_{k=1}^{n}\left(a_{i k}-a_{j k}\right)=(1 / n)$ $\sum_{k=1}^{n}\left(a_{i k}+a_{k j}\right)$, where $n$ is the number of evaluation indicators. So, $R$ is

$$
R=\left[\begin{array}{cccc}
r_{11} & r_{12} & \cdots & r_{1 j} \\
r_{21} & r_{22} & \cdots & r_{2 j} \\
\cdots & \cdots & \cdots & \cdots \\
r_{i 1} & r_{i 2} & \cdots & r_{i j}
\end{array}\right]
$$

Matrix $D$ is the judgment matrix for matrix $R$, and each element value in matrix $D$ can be calculated using equation $d_{i j}=\exp \left(r_{i j}\right)$. So, $D$ is

$$
D=\left[\begin{array}{cccc}
d_{11} & d_{12} & \cdots & d_{1 j} \\
d_{21} & d_{22} & \cdots & d_{2 j} \\
\cdots & \cdots & \cdots & \cdots \\
d_{i 1} & d_{i 2} & \cdots & d_{i j}
\end{array}\right]
$$

Weight $\omega_{i}$ of a single indicator factor can be calculated using Equation (4) according to each element value in matrix $D$ :

$$
\omega_{i}=\frac{\sqrt[n]{\coprod_{k=1}^{n} d_{i k}}}{\sum_{k=1}^{n} \sqrt[n]{\coprod_{k=1}^{n} d_{i k}}}
$$

\subsection{Extension Matter Element Model}

2.2.1. Basic Theory. Everything has its own unique properties, and each differs from other things. The extension matter element theory $[25,26]$ is a new theory that describes the internal structural relationship and attribute changes for things. If $M$ is the thing described, then $C$ is a feature of thing $M$ and $V$ is the magnitude of feature $C$. Thus, the matter element matrix for the thing is

$$
R=(M, C, V)
$$

In general, a thing has many characteristics, and the matrix of matter elements with $n$ features is

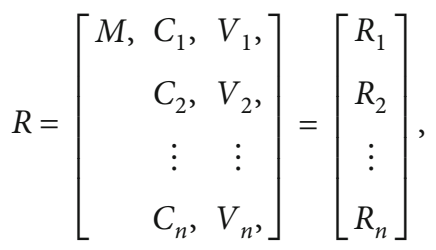

where $R_{i}=\left(M, C_{i}, V_{i}\right), i=1,2, \cdots, n$.

2.2.2. Model Establishment. Assuming that $n$ factors affect karst development, then the degree of karst development can be divided into $\mathrm{H}$ grades. The matter element matrix of grade $j$ can be expressed as

$R_{j}=\left[\begin{array}{ccc}M_{j}, & C_{1}, & V_{j 1}, \\ & C_{2}, & V_{j 2}, \\ \vdots & \vdots \\ & C_{n}, & V_{j n},\end{array}\right]=\left[\begin{array}{ccc}M_{j} & C_{1} & <x_{j 1}, y_{j 1}> \\ & C_{2} & <x_{j 2}, y_{j 2}> \\ \vdots & \vdots \\ & C_{n} & <x_{j n}, y_{j n}>\end{array}\right]$,

where $R_{j}$ denotes the matter element matrix when the degree of karst development is grade $j, M_{j}$ is the $j$ th grade of karst development, and $V_{j i}=\left\langle x_{j i}, y_{j i}\right\rangle$ denotes the range of values when the first index that affects karst development is grade $j$, $j=1,2, \cdots, h, i=1,2, \cdots, n$.

For all levels of $h$, the nodal matter element matrix comprising the allowable range for each index factor is as follows:

$$
R_{D}=\left(D, C, V_{D}\right)=\left[\begin{array}{ccc}
D & C_{1} & <x_{D 1}, y_{D 1}> \\
& C_{2} & <x_{D 2}, y_{D 2}> \\
\vdots & \vdots \\
& C_{n} & <x_{D n}, y_{D n}>
\end{array}\right] \text {, }
$$

where $R_{D}$ represents the nodal matter element matrix of the karst development degree, $D$ is the set of karst development degree grades, and $V_{D i}=\left\langle x_{D i}, y_{D i}\right\rangle$ is the allowable range of index factor $C_{i}$ in $D . V_{j i} \in V_{D i}$, $j=1,2, \cdots, h, i=1,2, \cdots, n$.

2.2.3. Extension Material Evaluation. 2.2.3.1. Definition of Proximity. For the evaluated things expressed by Equation (6), let

$$
\begin{aligned}
& p\left(V_{i}, V_{j i}\right)=\left|V_{i}-\frac{x_{j i}+y_{j i}}{2}\right|-\frac{1}{2}\left(y_{j i}-x_{j i}\right), \\
& p\left(V_{i}, V_{D i}\right)=\left|V_{i}-\frac{x_{D i}+y_{D i}}{2}\right|-\frac{1}{2}\left(y_{D i}-x_{D i}\right) .
\end{aligned}
$$

In the formula, $V_{i}$ is the measure of the evaluation index factor; $p\left(V_{i}, V_{j i}\right)$ and $p\left(V_{i}, V_{D i}\right)$ represent the "proximity" of $V_{i}$ to intervals $V_{j i}$ and $V_{D i}$, respectively; $p\left(V_{i}, V_{D i}\right)>0$ 

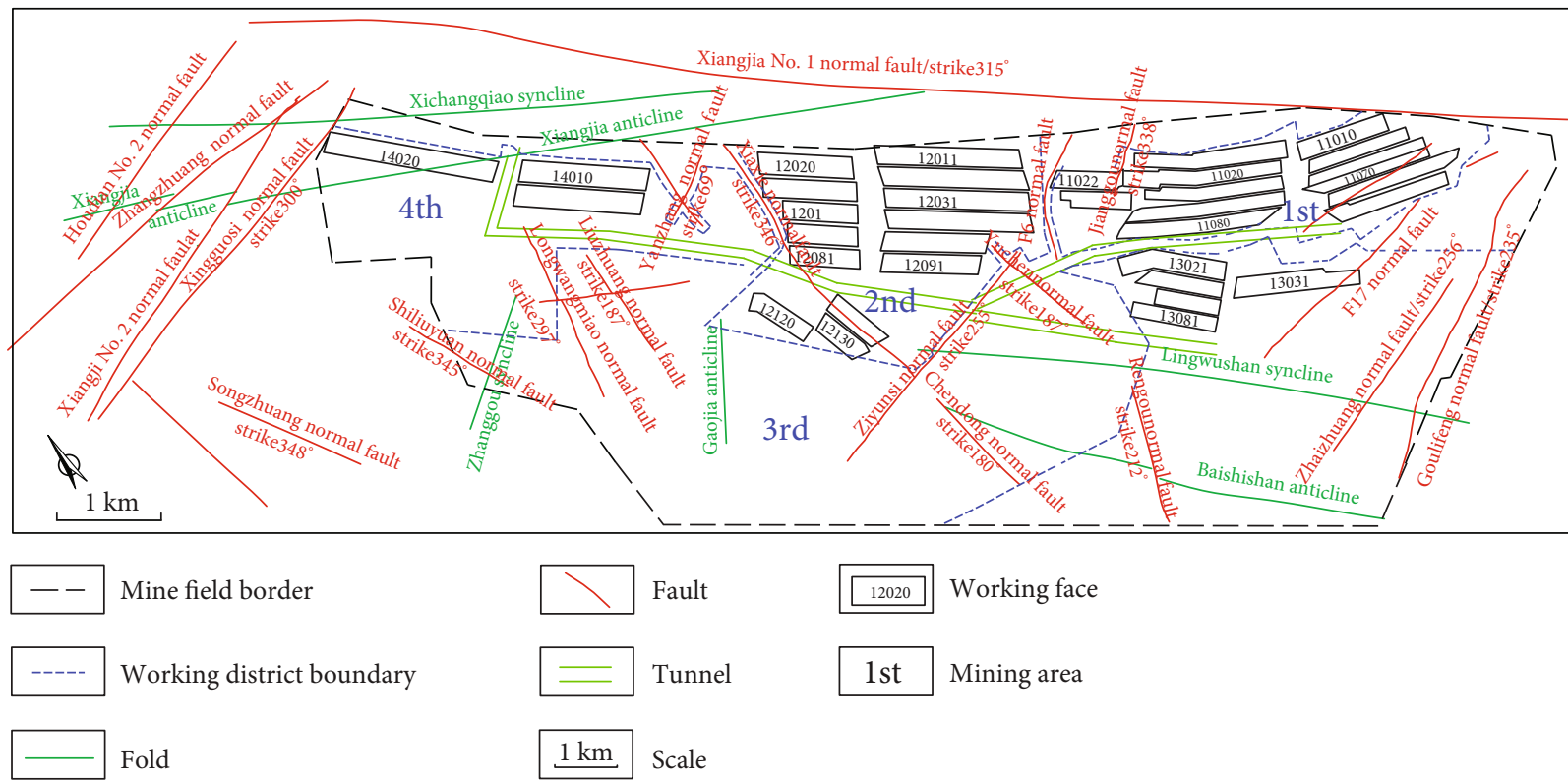

FIgURE 1: Distribution map of the mining area and geological structure of mine No. 13.

denotes that $V_{i}$ is not in the interval $V_{D i}$; and $p\left(V_{i}, V_{D i}\right) \leq 0$ denotes that $V_{i}$ is in the interval $V_{D i}$.

(1) Relevance Evaluation. Then,

$$
K_{j}\left(V_{i}\right)= \begin{cases}-\frac{p\left(V_{i}, V_{j i}\right)}{\left|v_{i}\right|}, & V_{i} \in V_{j i}, \\ \frac{p\left(V_{i}, V_{j i}\right)}{p\left(V_{i}, V_{D i}\right)-p\left(V_{i}, V_{j i}\right)}, & V_{i} \notin V_{j i} .\end{cases}
$$

In the formula, $K_{j}\left(V_{i}\right)$ is the correlation between the karst development degree and defined grade.

To evaluate object $M$, the comprehensive correlation with grade $j$ is as follows:

$$
K_{j}(M)=\sum_{i=1}^{n} \omega_{i} K_{j}\left(V_{i}\right)
$$

where $\omega_{i}$ is the index factor weight calculated using the formula.

The evaluation grade can be determined by selecting the maximum value of the comprehensive correlation degree:

$$
K_{S}(M)=\max K_{j}(M) .
$$

\section{Hydrogeological Characteristics of the Study Domain}

3.1. Geological Characteristics. The mine No. 13 of the Pingdingshan coalfield (abbreviated as mine No. 13) is located $17 \mathrm{~km}$ northeast of Pingdingshan City, in Henan Province, China. At present, $\mathrm{Ji}_{15,17}$ coal seam of Shanxi
TABLE 1: Undermine water inflow of mine No. $13\left(\mathrm{~m}^{3} / \mathrm{h}\right)$.

\begin{tabular}{lccc}
\hline Position & $\begin{array}{c}\text { Minimum } \\
\text { value }\end{array}$ & $\begin{array}{c}\text { Maximum } \\
\text { value }\end{array}$ & $\begin{array}{c}\text { Average } \\
\text { value }\end{array}$ \\
\hline 1st mining area & 15 & 170 & 43.13 \\
2nd mining & 15 & 390 & 168.61 \\
area & 20 & 220 & 114.87 \\
3rd mining area & 145 & 190 & 162.18 \\
4th mining area & 180 & 550 & 353.57 \\
The whole mine & & & \\
\hline
\end{tabular}

Formation of Permian is mainly mined (Ji coal for short). The mine is bounded by the normal faults of Xingguosi and Goulifeng on its northwestern and southeastern sides, respectively. Its northeastern side is bounded by the outcrop of the coal seam of the Ji group, and the southwestern side by the contour line of the $800 \mathrm{~m}$ floor. The dimensions of the mine are approximately $15 \mathrm{~km}$ long and $2.3-5 \mathrm{~km}$ wide; the area of the minefield is about $53.6 \mathrm{~km}^{2}$. Currently, the main coal mining is the Shanxi group of the Permian era, which has been divided into the 1st, 2nd, 3rd, and 4th mining area in the plane (as shown in Figure 1). The 1st and 2nd mining areas have both been excavated. The analysis of the actual monitoring data since June 2006 showed that the total mine water inflow in mine No. 13 ranged from 180 to $550 \mathrm{~m}^{3} / \mathrm{h}$, with an average of $353.57 \mathrm{~m}^{3} / \mathrm{h}$. The underground water inflow values and the mean values in the four mining areas are shown in Table 1.

The main structure of mine No. 13 is the southwestern wing of the Xiangjia anticline, while the northwestern part is a monoclinic structure. The southeastern part is affected by the wedging of the Lingwushan syncline and the Baishishan anticline, both of which are accompanied by faults. During the exploration of the minefield, 26 faults were 
found, which can be divided into five groups according to their direction: A $\left(355^{\circ}\right), \mathrm{B}\left(70^{\circ}\right), \mathrm{C}\left(45^{\circ}\right), \mathrm{D}\left(300^{\circ}\right)$, and $\mathrm{E}$ $\left(315^{\circ}\right)$. Among them, the Xiangjia No. 1 normal fault distributes throughout the whole mining area of the mine and blocks the hydraulic connection between the mine and the outside. The Goulifeng normal fault in the 3rd mining area and the Xingguosi, Xiangjia No. 2, and Zhangzhuang normal faults in the 4 th mining area also block the hydraulic connection between the mine and the outside. The Xiaxie, Ziyunsi, and Jianggou faults in the 1st and 2nd mining areas and the Rengou, Zhaizhuang, Chendong, Longwangmiao, Shiliuyuan, and Yanzhang normal faults in the 3rd mining area have destroyed the integrity of the limestone aquifer to varying degrees and should have an impact on future mining operations. The geological structure distribution of the mine is shown in Figure 1.

3.2. Main Aquifer Characteristics. Two main soluble aquifer groups exist in the Ji coal seam floor in the minefield. From bottom to top, the Cambrian limestone (CL for short) karst fissure aquifer group and the Carboniferous Taiyuan group, which is a thin limestone karst fissure aquifer group, are found (Figure 2). In general, the soluble aquifer group located on the northwest side of the fourth mining area was shallowly buried, and it was the recharge zone for the karst groundwater. The natural groundwater level was high in the northwest and low in the southeast.

The oolitic limestone of the Cambrian Zhangxia Group and the dolomitic limestone of the Gushan group are $200 \mathrm{~m}$ thick and constitute the most developed karst strata in the coalfield. CL was determined in 112 boreholes (including underground exploration and drainage holes; see Table 2) in mine No. 13. The thickness of the exposed limestone was 0.55-155 m, and the maximum height of the karst cave was $1.37 \mathrm{~m}$. The unit water inflow of the aquifer is from an indirect water-filling aquifer of the Ji coal floor, and its value is $0.0226 \mathrm{~L} /(\mathrm{s} \cdot \mathrm{m})$. The water level in the Cambrian aquifer was between $-493 \mathrm{~m}$ and $-650 \mathrm{~m}$, and the water level in the fourth mining area was higher than that in the third mining area.

There were 25 boreholes (including underground exploration holes and drainage holes; see Table 2) in the Carboniferous Taiyuan group limestone and $112 \mathrm{CL}$ boreholes in all of the strata in the Taiyuan group. Exploration data show that the Carboniferous Taiyuan group has a total thickness of about $50-75 \mathrm{~m}$ and is composed of limestone, sandstone, mudstone, and coal alternately deposited by sea and land. A total of seven thin layers of limestone, named $\mathrm{L}_{1}-\mathrm{L}_{7}$ from top to bottom (Figure 2), are sandwiched within the group, for a total thickness of about $20 \mathrm{~m}$. In order to distinguish the effects of the $\mathrm{L}_{1}-\mathrm{L}_{7}$ thin layer of limestone on the Ji coal mine, the $\mathrm{L}_{1}-\mathrm{L}_{7}$ limestone was divided into $\mathrm{L}_{1}-\mathrm{L}_{4}$ and $\mathrm{L}_{5}-\mathrm{L}_{7}$ aquifer groups with a boundary at the Geng20 coal seam. In particular, $\mathrm{L}_{1}-\mathrm{L}_{4}$ was the direct water-filled aquifer group in the coal bottom plate, where the water level was between $-352 \mathrm{~m}$ and $600 \mathrm{~m} . \mathrm{L}_{5}-\mathrm{L}_{7}$ was the indirect water-filled aquifer in the coal floor, where the water level was between $-420 \mathrm{~m}$ and $-660 \mathrm{~m}$.

3.3. Hydrochemical Characteristics. According to the water quality test results for eight $\mathrm{L}_{1}-\mathrm{L}_{7}$ limestone water samples and $12 \mathrm{CL}$ groundwater samples, Table 3 shows the main ionic components in the groundwater from different aquifers in mine No. 13. The cations were mainly $\mathrm{Na}^{+}$and $\mathrm{Ca}^{2+}$, the anions were mainly $\mathrm{HCO}_{3}{ }^{-}$and $\mathrm{SO}_{4}{ }^{2-}$, and the water chemical types were all the $\mathrm{HCO}_{3} \cdot \mathrm{SO}_{4}$ - Na.Ca type. The total dissolved solids did not exceed $1 \mathrm{~g} / \mathrm{L}$. The overall trend indicated that the total dissolved solid contents increased as the depth of the aquifer group increased.

\section{Evaluation of the Degree of Karst Development}

4.1. Evaluation Index. The occurrence and development of karst are controlled mainly by the geological conditions, hydrogeological conditions, and water chemistry conditions. The geological conditions mainly include the formation lithology, rock thickness, burial depth, and geological structure; the hydrogeological conditions mainly comprise the hydrodynamic cycle characteristics; and the main water chemistry component is the free $\mathrm{CO}_{2}$ content of the groundwater.

Based on previous results and the information for mine No. 13, we selected five indicators comprising the limestone lithology, limestone thickness, burial depth, geological structure, and water circulation capacity in order to evaluate the degree of karst development.

The analysis of the 25 Carboniferous Taiyuan group boreholes and the $112 \mathrm{CL}$ boreholes in mine No. 13 (Table 2) showed that the mineral composition of the $\mathrm{L}_{1}-\mathrm{L}_{4}$ limestone was mainly limestone, whereas that of the $\mathrm{L}_{5}-\mathrm{L}_{7}$ limestone was mainly dolomitic limestone, and that of the CL was mainly dolomitic and oolitic limestone. Under the same conditions, homogeneous limestone is more prone to dissolution, so the $\mathrm{L}_{1}-\mathrm{L}_{4}$ thin limestone was vulnerable to dissolution. The dissolution rate under the action of a water flow will be faster when the limestone is thicker, and thus, the dissolution rate was faster in the CL. The overlying rock and the density of limestone are lower when the burial depth is shallower. Thus, the shallow $\mathrm{L}_{1}-\mathrm{L}_{7}$ limestone at the same location was more conducive to the occurrence of dissolution than the CL.

The geological tectonic properties and developmental degree have important effects on the flow of groundwater and the storage of $\mathrm{CO}_{2}$ in limestone, thereby controlling the rate of dissolution.

Limestone is dissolved more readily when the groundwater circulation capacity is stronger. Therefore, the fourth mining area located in the recharge zone of the soluble aquifer group was more vulnerable to the occurrence and development of dissolution than the other mining areas.

The dissolution of limestone is stronger when the free $\mathrm{CO}_{2}$ content of groundwater is higher. The current $\mathrm{L}_{1}-\mathrm{L}_{7}$ limestone borehole collapsed due to mining, so it was not possible to extract a water sample to test the free $\mathrm{CO}_{2}$ content. Therefore, the free $\mathrm{CO}_{2}$ content was not employed as an index factor for evaluating the karst development degree in this study.

In addition, a previous study [22] evaluated the degree of karst development by using the limestone water-richness as one of the indicators. The main factors that affect water- 


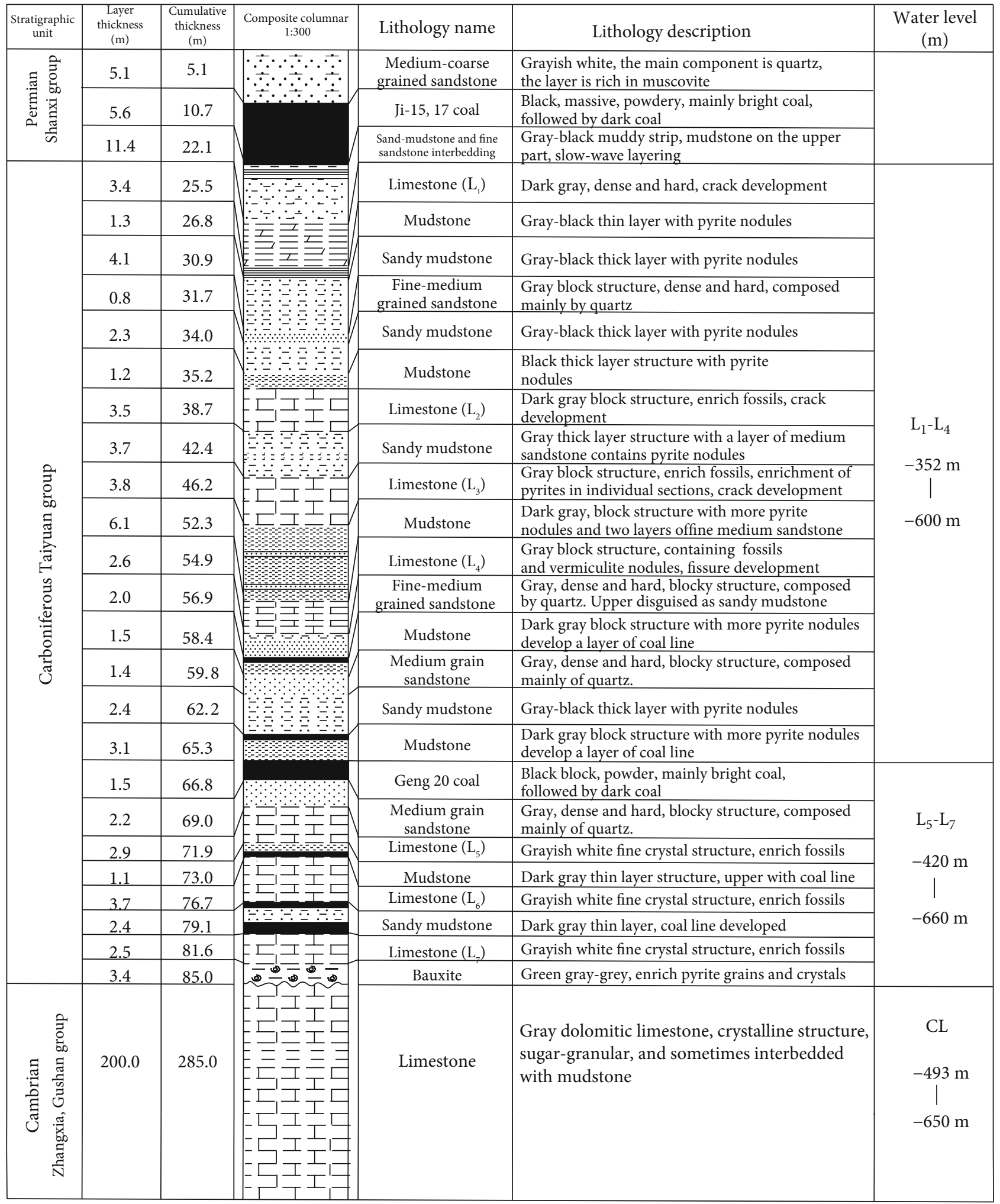

Figure 2: Column diagram of the Ji coal floor in mine No. 13.

rich limestone are considered to be the limestone lithology, geological structure, and water cycle capacity, and thus, these factors were used as evaluation factors. Therefore, the water from the water-rich limestone was not used as an evaluation index factor.
4.2. Index Grading and Quantification. According to a previous study [15] and the actual situation in mine No. 13, the karst development degree was divided into five grades: no development $=\mathrm{I}$, weak development $=\mathrm{II}$, moderate development $=$ III, high development $=I V$, and 
TABLE 2: The number and depth of hydrogeological boreholes in mining areas.

\begin{tabular}{lcccc}
\hline \multirow{2}{*}{ Mining area } & \multicolumn{2}{c}{ Carboniferous Taiyuan limestone } & \multicolumn{2}{c}{ Cambrian limestone } \\
& Quantity (number) & Hole depth (min-max, m) & Quantity (number) & Hole depth (min-max, m) \\
\hline First & 5 & $79-110$ & 5 & $151-237$ \\
Second & 4 & $95-110$ & 3 & $145-226$ \\
Third & 5 & $75-97.5$ & 35 & $81-253.5$ \\
Fourth & 11 & $48-155$ & 69 & $80-272.0$ \\
Total & 25 & & 112 & \\
\hline
\end{tabular}

TABLE 3: Contents of main ionic components in groundwater in different aquifers of mine No. 13 (mg/L).

\begin{tabular}{lccccccrrr}
\hline \multirow{2}{*}{ Aquifer groups } & & \multicolumn{4}{c}{ Main ion content } & \multicolumn{3}{c}{ Total hardness } \\
& $\mathrm{Na}^{+}+\mathrm{K}^{+}$ & $\mathrm{Ca}^{2+}$ & $\mathrm{Mg}^{2+}$ & $\mathrm{Cl}^{-}$ & $\mathrm{SO}_{4}{ }^{2-}$ & $\mathrm{HCO}_{3}{ }^{-}$ & (calculated as CaCO & TDS & $\mathrm{pH}$ \\
\hline $\mathrm{L}_{1}-\mathrm{L}_{4}$ & 90.28 & 67.90 & 36.09 & 46.16 & 128.29 & 365.75 & 318.05 & 551.60 & 7.2 \\
$\mathrm{~L}_{5}-\mathrm{L}_{7}$ & 103.38 & 69.38 & 35.18 & 55.94 & 140.15 & 365.75 & 318.00 & 586.91 & 7.1 \\
$\mathrm{CL}$ & 169.03 & 77.82 & 38.49 & 88.77 & 277.95 & 336.71 & 352.68 & 820.42 & 7.3 \\
\hline
\end{tabular}

TABLE 4: Classification of evaluation indexes for the karst development degree.

\begin{tabular}{|c|c|c|c|c|c|c|}
\hline Index factor & $\begin{array}{c}\text { Characteristic and } \\
\text { assignment }\end{array}$ & A (I) & B (II) & $\begin{array}{l}\text { Index level } \\
\text { C (III) }\end{array}$ & $\mathrm{D}(\mathrm{IV})$ & $\mathrm{E}(\mathrm{V})$ \\
\hline \multirow{3}{*}{$\begin{array}{l}\text { Limestone } \\
\text { lithology }\end{array}$} & Feature & (1) & (2) & (3) & (4) & (5) \\
\hline & Definition & Insoluble & Microsoluble & Relatively soluble & Soluble & Highly soluble \\
\hline & Assignment & 1 & 2 & 3 & 4 & 5 \\
\hline \multirow{2}{*}{$\begin{array}{l}\text { Limestone } \\
\text { thickness (m) }\end{array}$} & Feature & $0-5$ & $5-10$ & $10-30$ & $30-100$ & $>100$ \\
\hline & Definition & Thin & Slightly thick & Medium thick & Thick & Extremely thick \\
\hline \multirow{2}{*}{ Buried depth (m) } & Feature & $>1200$ & $900-1200$ & $600-900$ & $300-600$ & $<300$ \\
\hline & Definition & Extremely deep & Deep & Medium depth & Shallow & Very shallow \\
\hline \multirow[t]{3}{*}{$\begin{array}{l}\text { Hydrodynamic } \\
\text { cycle }\end{array}$} & Feature & $\begin{array}{l}\text { Confined water } \\
\text { zone with } \\
\text { slightly } \\
\text { varying water } \\
\text { level }\end{array}$ & $\begin{array}{l}\text { Confined water } \\
\text { zone } \\
\text { with seasonal } \\
\text { variation } \\
\text { of water level }\end{array}$ & $\begin{array}{l}\text { Confined water } \\
\text { zone } \\
\text { with annual } \\
\text { water } \\
\text { level change }\end{array}$ & Diving belt & $\begin{array}{l}\text { Water-air } \\
\text { mixing zone }\end{array}$ \\
\hline & Definition & Disadvantageous & $\begin{array}{c}\text { Slightly } \\
\text { advantageous }\end{array}$ & $\begin{array}{c}\text { Relatively } \\
\text { advantageous }\end{array}$ & Advantageous & $\begin{array}{c}\text { Extremely } \\
\text { advantageous }\end{array}$ \\
\hline & Assignment & 1 & 2 & 3 & 4 & 5 \\
\hline \multirow{3}{*}{$\begin{array}{l}\text { Geological } \\
\text { structure }\end{array}$} & Feature & $\begin{array}{l}\text { Small faults or } \\
\text { folds }\end{array}$ & $\begin{array}{l}\text { Compressive } \\
\text { faults } \\
\text { or small folds }\end{array}$ & $\begin{array}{l}\text { Compression- } \\
\text { torsion } \\
\text { fault or fold wing }\end{array}$ & $\begin{array}{c}\text { Tensile faults or } \\
\text { anticlinal } \\
\text { axes or fold turning } \\
\text { points }\end{array}$ & $\begin{array}{c}\text { Tension-torsion } \\
\text { fault } \\
\text { or syncline axis }\end{array}$ \\
\hline & Definition & No development & $\begin{array}{c}\text { Weak } \\
\text { development }\end{array}$ & $\begin{array}{c}\text { Relative } \\
\text { development }\end{array}$ & Development & $\begin{array}{c}\text { Extreme } \\
\text { development }\end{array}$ \\
\hline & Assignment & 1 & 2 & 3 & 4 & 5 \\
\hline
\end{tabular}

Remarks: (1) A: not conducive to karst development; B: slightly favorable to karst development; C: relatively favorable for karst development; D: conducive to karst development; E: highly conducive to karst development. (2) (1): nonuniform marl, metamorphic carbonate rock; (2): uniform marl, nonuniform oolitic limestone; (3): uniform oolitic limestone, nonuniform dolomitic limestone; (4): uniform dolomitic limestone, nonuniform limestone, (5): uniform limestone.

very high development $=\mathrm{V}$. The characteristics of the evaluation index factors corresponding to the five grades were determined via the hydrogeological boreholes, and the results are shown in Table 4.

In order to facilitate quantitative analyses, five evaluation index factors were quantitatively assigned. The assignment method involved allocating three qualitative index factors (limestone lithology, geological structure, and water cycle conditions) with values from 1 to 5 according to the matching level $(\mathrm{I}-\mathrm{V})$. The rock thickness and burial depth were the actual measurements obtained from the boreholes, as shown in Table 4.

Based on the differences in karst development in the planar and vertical directions, mine No. 13 was divided 
TABLE 5: Quantitative evaluation index values for the degree of karst development.

\begin{tabular}{|c|c|c|c|c|c|c|c|c|c|}
\hline \multirow{3}{*}{$\begin{array}{l}\text { Aquifer } \\
\text { groups }\end{array}$} & \multirow{3}{*}{$\begin{array}{l}\text { Mining } \\
\text { areas }\end{array}$} & \multicolumn{8}{|c|}{ Evaluation index } \\
\hline & & \multicolumn{2}{|c|}{ Limestone lithology } & \multirow{2}{*}{$\begin{array}{l}\text { Limestone } \\
\text { thickness } \\
\text { Assignment }\end{array}$} & \multirow{2}{*}{$\begin{array}{c}\text { Buried } \\
\text { depth } \\
\text { Assignment }\end{array}$} & \multirow{2}{*}{$\begin{array}{c}\text { Hydrodynamic } \\
\text { cycle } \\
\text { Nature }\end{array}$} & \multicolumn{3}{|c|}{ Geological structure } \\
\hline & & Nature & $\begin{array}{l}\text { Quantitative } \\
\text { value }\end{array}$ & & & & Assignment & Nature & Assignment \\
\hline \multirow{4}{*}{$\mathrm{L}_{1}-\mathrm{L}_{4}$} & First & $\begin{array}{l}\text { Inhomogeneous } \\
\text { limestone }\end{array}$ & 4 & 15.8 & 425.8 & $\begin{array}{l}\text { Confined water } \\
\text { zone with annual } \\
\text { water level change }\end{array}$ & 3 & Fold wing & 3 \\
\hline & Second & $\begin{array}{l}\text { Inhomogeneous } \\
\text { limestone }\end{array}$ & 4 & 21.2 & 501.2 & $\begin{array}{l}\text { Confined water } \\
\text { zone with annual } \\
\text { water level change }\end{array}$ & 3 & Tensile fault & 4 \\
\hline & Third & $\begin{array}{l}\text { Uniform } \\
\text { limestone }\end{array}$ & 5 & 15.8 & 780.0 & $\begin{array}{l}\text { Water-air } \\
\text { mixing zone }\end{array}$ & 5 & $\begin{array}{l}\text { Superposition } \\
\text { of anticline } \\
\text { axis and fault }\end{array}$ & 5 \\
\hline & Fourth & $\begin{array}{l}\text { Uniform } \\
\text { limestone }\end{array}$ & 5 & 22.2 & 371.3 & $\begin{array}{l}\text { Water-air } \\
\text { mixing zone }\end{array}$ & 5 & $\begin{array}{l}\text { Superposition } \\
\text { of anticline } \\
\text { axis and fault }\end{array}$ & 5 \\
\hline \multirow{4}{*}{$\mathrm{L}_{5}-\mathrm{L}_{7}$} & First & $\begin{array}{c}\text { Inhomogeneous } \\
\text { dolomitic } \\
\text { limestone }\end{array}$ & 3 & 23.5 & 472.5 & $\begin{array}{c}\text { Confined water } \\
\text { zone with seasonal } \\
\text { variation of water } \\
\text { level }\end{array}$ & 2 & $\begin{array}{l}\text { Extension of } \\
\text { folded wing }\end{array}$ & 2 \\
\hline & Second & $\begin{array}{c}\text { Inhomogeneous } \\
\text { dolomitic } \\
\text { limestone }\end{array}$ & 3 & 30.1 & 650.5 & $\begin{array}{c}\text { Confined water } \\
\text { zone with slightly } \\
\text { varying water level }\end{array}$ & 1 & Minor fault & 2 \\
\hline & Third & $\begin{array}{l}\text { Uniform } \\
\text { dolomitic } \\
\text { limestone }\end{array}$ & 4 & 19.8 & 812.3 & $\begin{array}{l}\text { Confined water } \\
\text { zone with annual } \\
\text { water level change }\end{array}$ & 3 & $\begin{array}{l}\text { Axis extension } \\
\text { of folds }\end{array}$ & 2 \\
\hline & Fourth & $\begin{array}{l}\text { Uniform } \\
\text { dolomitic } \\
\text { limestone }\end{array}$ & 4 & 27.7 & 428.3 & $\begin{array}{c}\text { Water-air mixing } \\
\text { zone }\end{array}$ & 5 & $\begin{array}{l}\text { Superposition } \\
\text { of anticline } \\
\text { axis and fault }\end{array}$ & 4 \\
\hline \multirow{4}{*}{ CL } & First & $\begin{array}{c}\text { Inhomogeneous } \\
\text { dolomitic } \\
\text { limestone }\end{array}$ & 3 & 120.0 & 636.0 & $\begin{array}{c}\text { Confined water } \\
\text { zone with slightly } \\
\text { varying water level }\end{array}$ & 1 & $\begin{array}{l}\text { Extension of } \\
\text { folded wing }\end{array}$ & 2 \\
\hline & Second & $\begin{array}{c}\text { Inhomogeneous } \\
\text { dolomitic } \\
\text { limestone }\end{array}$ & 3 & 155.0 & 840.0 & $\begin{array}{c}\text { Confined water } \\
\text { zone with slightly } \\
\text { varying water level }\end{array}$ & 1 & Microfault & 1 \\
\hline & Third & $\begin{array}{l}\text { Uniform oolitic } \\
\text { limestone }\end{array}$ & 3 & 138.0 & 961.0 & $\begin{array}{c}\text { Confined water } \\
\text { zone with seasonal } \\
\text { variation of water } \\
\text { level }\end{array}$ & 2 & $\begin{array}{l}\text { Compressive } \\
\text { fault }\end{array}$ & 2 \\
\hline & Fourth & $\begin{array}{l}\text { Uniform } \\
\text { dolomitic } \\
\text { limestone }\end{array}$ & 4 & 139.0 & 594.2 & $\begin{array}{l}\text { Confined water } \\
\text { zone with annual } \\
\text { water level change }\end{array}$ & 3 & Small fold belt & 2 \\
\hline
\end{tabular}

into four mining areas in the planar direction, i.e., first, second, third, and fourth mining areas, and three aquifer groups in the vertical direction, i.e., $\mathrm{L}_{1}-\mathrm{L}_{4}, \mathrm{~L}_{5}-\mathrm{L}_{7}$, and CL. The characteristics and values quantified for the evaluation index factors in each aquifer group in the different mining areas are shown in Table 5.

The evaluation grade can be defined by choosing the maximum level of the comprehensive correlation degree calculated following equation (12) of the improved AHP multidimensional extension matter element model.

4.3. Index Weight. According to the complexity and particularity of geological structure in mine No. 13, and referring to expert opinions [28], the indexes for evaluating the degree of karst development are sorted by order of importance: limestone lithology $\left(C_{1}\right)$, limestone thickness $\left(C_{2}\right)$, burial depth $\left(C_{3}\right)$, water circulation capacity $\left(C_{4}\right)$, and geological structure $\left(C_{5}\right)$.

Substituting the matrix elements by value $C_{1}$ to $C_{5}$, judgment matrix $A$ is constructed as follows:

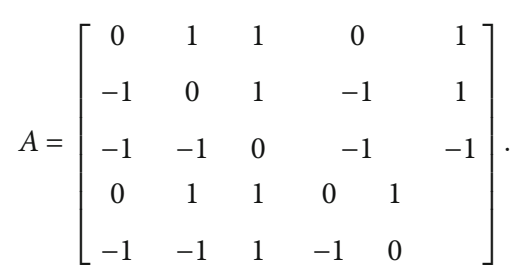


Using the improved AHP formula (4), the weight values of each index can be obtained:

$$
\begin{aligned}
\omega & =\left(C_{1} C_{2} C_{3} C_{4} C_{5}\right) \\
& =\left(\begin{array}{lll}
0.31610 .0780 & 0.17350 .31610 .1163
\end{array}\right) .
\end{aligned}
$$

4.4. Evaluation of Karst Development. The karst development degree was evaluated by considering the first mining area and the $\mathrm{L}_{1}-\mathrm{L}_{4}$ aquifer group as an example.

4.4.1. Matter Element Matrix and Nodal Domain Matrix. The degree of karst development can be divided into five grades, and the matter element matrix of each grade is as follows:

$$
\begin{aligned}
& R_{1}=\left[\begin{array}{ccc}
M_{1} & C_{1} & <0,1> \\
& C_{2} & <0,5> \\
& C_{3} & <1200,1500> \\
& C_{4} & <0,1> \\
& C_{5} & <0,1>
\end{array}\right] \text {, } \\
& R_{2}=\left[\begin{array}{ccc}
M_{2} & C_{1} & <1,2> \\
& C_{2} & <5,10> \\
& C_{3} & <900,1200> \\
& C_{4} & <1,2> \\
& C_{5} & <1,2>
\end{array}\right] \\
& R_{3}=\left[\begin{array}{ccc}
M_{3} & C_{1} & <2,3> \\
& C_{2} & <10,30> \\
& C_{3} & <600,900> \\
& C_{4} & <2,3> \\
& C_{5} & <2,3>
\end{array}\right] \text {, }
\end{aligned}
$$

$$
\begin{array}{r}
R_{4}=\left[\begin{array}{ccc}
M_{4} & C_{1} & <3,4> \\
& C_{2} & <30,100> \\
& C_{3} & <300,600> \\
& C_{4} & <3,4> \\
& C_{5} & <3,4>
\end{array}\right], \\
R_{5}=\left[\begin{array}{ccc}
M_{5} & C_{1} & <4,5> \\
& C_{2} & <100,200> \\
& C_{3} & <0,300> \\
& C_{4} & <4,5> \\
& C_{5} & <4,5>
\end{array}\right] .
\end{array}
$$

Following formula (8) and using the $5 R_{\mathrm{i}}$ matrices as input, the nodal matter element matrix is

$$
R_{D}=\left[\begin{array}{ccc}
D & C_{1} & <0,5> \\
& C_{2} & <0,200> \\
& C_{3} & <0,1500> \\
& C_{4} & <0,5> \\
& C_{5} & <0,5>
\end{array}\right] .
$$

Based on formula (6), the matrix of matter elements to be evaluated is constructed as follows:

$$
R=\left[\begin{array}{ccc}
M & C_{1} & 4 \\
& C_{2} & 15.18 \\
& C_{3} & 425.8 \\
& C_{4} & 3 \\
& C_{5} & 3
\end{array}\right] .
$$

4.4.2. Evaluation of Results. According to formulas (9), (10), and (11), the correlation between the karst development and definition grade (I-V) can be evaluated as follows:

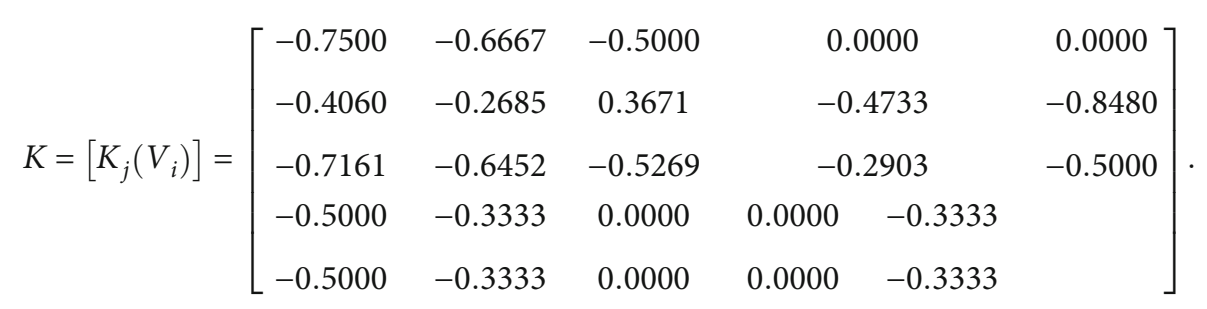


TABle 6: Degree of karst development of different aquifer groups in mine No. 13.

\begin{tabular}{|c|c|c|c|c|c|}
\hline \multirow{2}{*}{ Aquifer groups } & \multirow{2}{*}{ Mining areas } & \multirow{2}{*}{ Evaluation grade } & \multirow{2}{*}{ Definition } & \multicolumn{2}{|c|}{ Quantization value } \\
\hline & & & & Assignment & Average \\
\hline \multirow{4}{*}{$\mathrm{L}_{1}-\mathrm{L}_{4}$} & First & IV & Development & 4 & \multirow{4}{*}{4.5} \\
\hline & Second & IV & Development & 4 & \\
\hline & Third & $\mathrm{V}$ & Extreme development & 5 & \\
\hline & Fourth & $\mathrm{V}$ & Extreme development & 5 & \\
\hline \multirow{4}{*}{$\mathrm{L}_{5}-\mathrm{L}_{7}$} & First & III & Relative development & 3 & \multirow{4}{*}{3.75} \\
\hline & Second & III & Relative development & 3 & \\
\hline & Third & IV & Development & 4 & \\
\hline & Fourth & $\mathrm{V}$ & Extreme development & 5 & \\
\hline \multirow{4}{*}{ CL } & First & II & Weak development & 2 & \multirow{4}{*}{2.75} \\
\hline & Second & II & Weak development & 2 & \\
\hline & Third & III & Relative development & 3 & \\
\hline & Fourth & IV & Development & 4 & \\
\hline
\end{tabular}

The comprehensive correlation degree is

$$
\begin{aligned}
K_{j}(M)= & \sum_{i=1}^{5} \omega_{i} K_{j}\left(V_{i}\right)=(-0.6092-0.4877 \\
& -0.2208-0.0873-0.2966)
\end{aligned}
$$

which is $K_{1}=(-0.6092), \quad K_{2}(M)=(-0.4877), \quad K_{3}(M)=$ $(-0.2208), \quad K_{4}(M)=(-0.0873), \quad$ and $K_{5}(M)=(-0.2966)$; then,

$$
K_{s}(M)=\max K_{j}(M)=K_{4}(M)=-0.0873 .
$$

The maximum value of the comprehensive correlation degree is selected to define the evaluation grade, yielding a karst development level IV for the $\mathrm{L}_{1}-\mathrm{L}_{4}$ aquifer group in the 1st mining area of mine No. 13.

Similarly, the degree of karst development of other mining areas in $\mathrm{L}_{1}-\mathrm{L}_{4}$ limestone aquifer group can be defined, as shown in Table 6 . The karst development evaluation results for the $\mathrm{L}_{5}-\mathrm{L}_{7}$ and CL aquifer groups in different mining areas are shown in Table 6.

\section{Discussion}

The defined karst development levels were quantitatively evaluated to facilitate their description, where the value of level I was assigned as 1, the value of level II as 2, the value of level III as 3, the value of level IV as 4, and the value of level $\mathrm{V}$ as 5. Quantitative evaluation of karst development in different mining areas of the same aquifer group is shown in Table 6 and Figure 3. Obviously, the degree of development of $\mathrm{L}_{1}-\mathrm{L}_{4}$ karst in the Carboniferous Taiyuan group belongs to grade IV-V with an average quantitative value of 4.5 , and that of $\mathrm{L}_{5}-\mathrm{L}_{7}$ in the Taiyuan group belongs to grade III- $\mathrm{V}$ with an average quantitative value of 3.75 , while the CL belongs to grade II-IV and has an average quantitative value of 2.75. This means that the degree of karst development decreases from the shallow $\mathrm{L}_{1}-\mathrm{L}_{4}$ to $\mathrm{L}_{5}-\mathrm{L}_{7}$ and then to the

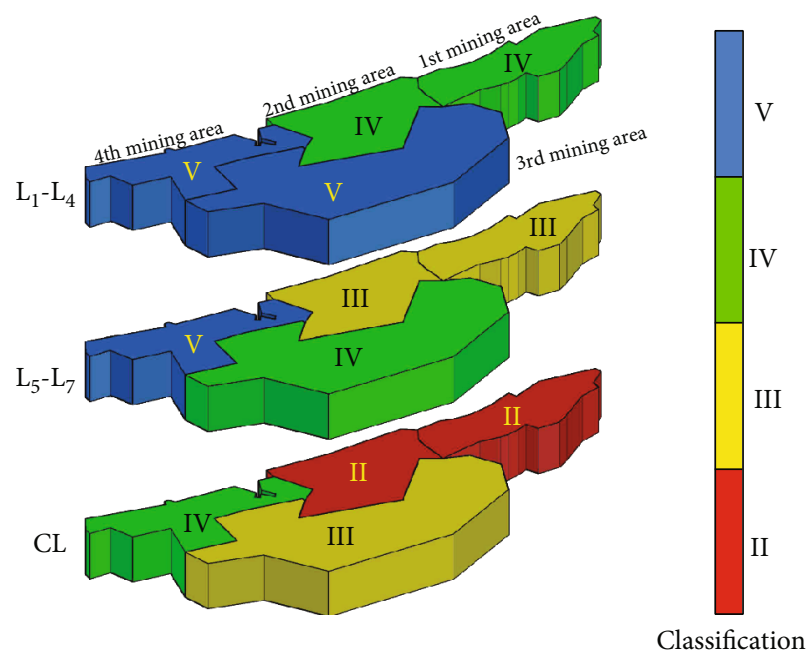

FIGURE 3: Diagrammatic drawing for quantitative evaluation of karst development.

deep CL. This decrease of the degree of development with increased depth can be explained by the typical attributes of a shallow layer because the burial depth of the rock layer is shallow, atmospheric rainfall is more easily assimilated, Quaternary groundwater recharge occurs, and the speed of the groundwater circulation is fast, leading the degree of karst development to be relatively high. In addition, for a shallow stratum burial depth, the load of the upper strata is smaller, and the lithology loose, which also leads to the smooth movement of groundwater.

The quantitative assignment of the karst development degree in different aquifer groups in the same mining area is shown in Table 7. Obviously, the degree of karst development of the 1 st and 2 nd mining areas belongs to grade II-IV and has an average quantitative value of 3.0, whereas the development degree of the 3rd mining area is grade III-V, with an average quantitative value of 4.0. Lastly, the 4 th mining area has a grade IV-V development degree, with an average quantitative value of 4.7 , i.e., the level of karst development in the mining 
TABle 7: Degree of karst development in different mining areas of mine No. 13.

\begin{tabular}{lccccc}
\hline Mining areas & Aquifer groups & Evaluation grade & Definition & Quantization value \\
Average
\end{tabular}

area of mine No. 13 is the highest in 4th, followed by 3rd, and then 1 st and 2 nd. This is mainly caused by the geological structure of the 1st and 2nd mining areas being weaker than that of the 3rd and 4th mining areas (as shown in Figure 1). The degree of karst development in the 4th mining area is the highest because the limestone aquifer is relatively shallow. The degree of karst development of the 1st and 2nd mining areas is similar as this mining area was artificially divided for the sake of mining management, although their geological and hydrogeological conditions are similar.

Due to the lack of detection data, the free $\mathrm{CO}_{2}$ content in the groundwater was not utilized in the evaluations of karst development in this study. However, the water quality analysis results for mine No.8 located adjacent to mine No. 13 (July 14, 2016) showed that the free $\mathrm{CO}_{2}$ content in the $\mathrm{CL}$ groundwater was $17.95 \mathrm{mg} / \mathrm{L}$, where this was the water obtained from the mixing of the water from the $\mathrm{CL}$ and the $\mathrm{L}_{1}-\mathrm{L}_{7}$ limestone. The free $\mathrm{CO}_{2}$ content in the water from the $\mathrm{L}_{1}-\mathrm{L}_{7}$ limestone was $15.96 \mathrm{mg} / \mathrm{L}$, and the difference was only $1.99 \mathrm{mg} / \mathrm{L}$. These results indicate that the difference in the free $\mathrm{CO}_{2}$ content between the $\mathrm{CL}$ and the $\mathrm{L}_{1}-\mathrm{L}_{7}$ limestone groundwater was very small. Therefore, the free $\mathrm{CO}_{2}$ content may have only slightly affected the karst development evaluation results.

In contrast to the linear analysis of karst development in a previous study of railway tunnel engineering, we quantitatively evaluated the differences in the karst development degree in the planar and vertical directions. Our results provide a useful reference method for similar research, and they have important practical significance for guiding the prevention and control of floor water hazards similar to that found in mine No. 13 in Ji coal.

\section{Conclusion}

(1) Based on the improved analytic hierarchy process (AHP) and the use of the multidimensional extension matter element model, five factors, including limestone lithology, limestone thickness, burial depth, hydrodynamic cycle, and geological structure, were selected to quantitatively evaluate the karst development degree of the Pingdingshan coalfield mine No. 13. This provided a reference method for objectively and clearly evaluating the degree of development of limestone karst

(2) The karst development of mine No. 13 shows large horizontal differences. The 1 st and 2 nd mining areas have a grade II-IV karst development with an average quantification value of 3.0. The grade of the 3rd mining area is III- $\mathrm{V}$, with an average quantization value of 4.0, and the 4th mining area belongs to grade IV$\mathrm{V}$, for an average quantization value of 4.7. That is, the degree of karst development of the 4th mining area is the highest overall, followed by the 3rd mining area, whereas the 1 st and 2 nd mining areas are the least developed

(3) The karst development of mine No. 13 is stratified in the vertical direction, reaching grades IV-V (average quantitative value of 4.5), III-V (average quantitative value of 3.75), and II-IV (average quantitative value of 2.75) for the $\mathrm{L}_{1}-\mathrm{L}_{4}$ in the Taiyuan Carboniferous group, the $\mathrm{L}_{5}-\mathrm{L}_{7}$, and the $\mathrm{CL}$, respectively. That is, the degree of karst development gradually decreases from shallow to deep levels

\section{Data Availability}

The data in this paper were derived from the actual survey data in the mining process of No. 13 coal mine, including borehole data (borehole histogram), drainage water, and other related data, and the source is real and reliable.

\section{Conflicts of Interest}

The authors declare that they have no conflicts of interest. 


\section{Acknowledgments}

This work was supported by the National Natural Science Foundation of China (Grants 41672240, 41802186, and 41972254), the Innovation Scientists and Technicians Troop Construction Projects of Henan Province (Grant CXTD2016053), the Fundamental Research Funds for the Universities of Henan Province (NSFRF1611), and the Henan Province Natural Science Foundation (182300410155).

\section{References}

[1] Y. Hao, B. Cao, P. Zhang, Q. Wang, Z. Li, and T. C. J. Yeh, "Differences in karst processes between northern and southern China," Carbonates and Evaporites, vol. 27, no. 3-4, pp. 331342, 2012.

[2] T. Geyer, S. Birk, T. Reimann, N. Dörfliger, and M. Sauter, "Differentiated characterization of karst aquifers: some contributions," Carbonates and Evaporites, vol. 28, no. 1-2, article 150, pp. 41-46, 2013.

[3] T. Mccormack, Y. O’Connell, E. Daly et al., "Characterisation of karst hydrogeology in Western Ireland using geophysical and hydraulic modelling techniques," Journal of Hydrology: Regional Studies, vol. 10, pp. 1-17, 2017.

[4] X. Li and Y. Wang, "Identification of hydrochemical function and behavior of the Houzhai karst basin, Guizhou Province, Southwestern China," Advances in Civil Engineering, vol. 2018, 8 pages, 2018.

[5] A. Kovács, P. Perrochet, E. Darabos, L. Lénárt, and P. Szűcs, "Well hydrograph analysis for the characterisation of flow dynamics and conduit network geometry in a karst aquifer, Bükk Mountains, Hungary," Journal of Hydrology, vol. 530, no. 2, pp. 484-499, 2015.

[6] D. S. Sokolov, Main Conditions for Karst Development, Gosgeol Tech Izdat, Moscow, Russia, 1962.

[7] H. E. Legrand and V. T. Stringfield, "Karst hydrology - a review," Journal of Hydrology, vol. 20, no. 2, pp. 97-120, 1973.

[8] Karst Research Group and Institute of Geology, Chinese Academy of Sciences. Karst Research of China, The Science Publishing Company, 1979.

[9] D. Ford and P. W. Williams, Karst Hydrogeology and Geomorphology, Wiley, 2007.

[10] J. J. Fornós, A. Merino, J. Ginés, A. Ginés, and F. Gràcia, “Solutional features and cave deposits related to hypogene speleogenetic processes in a littoral cave of Mallorca Island (western Mediterranean)," Carbonates and Evaporites, vol. 26, no. 1, pp. 69-81, 2011.

[11] P. Huang and X. Wang, "Applying environmental isotope theory to groundwater recharge in the Jiaozuo mining area, China," Geofluids, vol. 2017, Article ID 9568349, 11 pages, 2017.

[12] M. Lancia, M. Saroli, and M. Petitta, "A double scale methodology to investigate flow in karst fractured media via numerical analysis: the Cassino plain case study (Central Apennine, Italy)," Geofluids, vol. 2018, Article ID 2937105, 12 pages, 2018.

[13] B. Yao, Z. Chen, J. Wei, T. Bai, and S. Liu, "Predicting erosioninduced water inrush of karst collapse pillars using inverse velocity theory," Geofluids, vol. 2018, Article ID 2090584, 18 pages, 2018.
[14] F. Sauro, D. Zampieri, and M. Filipponi, "Development of a deep karst system within a transpressional structure of the Dolomites in north-east Italy," Geomorphology, vol. 184, pp. 51-63, 2013.

[15] C. Guosheng, P. Guoying, Q. Yongtai, and D. Pengzhuo, "Analysis on difference karstification and karst development mechanism in Pingdingshan mining area," Zhongzhou Coal, vol. 8, pp. 116-120, 2015.

[16] M. Chitsazan, H. Karimi Vardanjani, H. Karimi, and A. Charchi, "A comparison between karst development in two main zones of Iran: case study-Keyno anticline (Zagros Range) and Shotori anticline (Central Iran)," Arabian Journal of Geosciences, vol. 8, no. 12, pp. 10833-10844, 2015.

[17] Z. Zhou, S. Zhang, K. Xiong et al., "The spatial distribution and factors affecting karst cave development in Guizhou Province," Journal of Geographical Sciences, vol. 27, no. 8, pp. 1011-1024, 2017.

[18] L. L. Sun, Z. H. Wang, H. J. Wang, Y. H. Wang, and Y. Q. Sun, "Detection research on water abundance of floor aquifers," Mining Safety \& Environmental Protection, vol. 40, no. 1, pp. 61-64, 2013.

[19] M. Lipar and J. A. Webb, "The formation of the pinnacle karst in Pleistocene aeolian calcarenites (Tamala Limestone) in southwestern Australia," Earth-Science Reviews, vol. 140, no. 5, pp. 182-202, 2015.

[20] C. Li, Y. Liao, and D. Ding, "Study on karst development in tunnels by hydrochemical kinetics-fractal index evaluation technology," Modern Tunnelling Technology, vol. 6, pp. 2431, 2017.

[21] L. Cangsong, W. Fengshou, Z. Yanjie, W. Fugang, and C. Yuqing, "Fractal and hydro-chemical characteristics of microscopic karst morphology based on dissolution experiments," Modern Tunnelling Technology, vol. 55, no. 2, pp. 110-120, 2018.

[22] K. Zhang, X. Huo, S. Chen, P. Tu, and X. Tan, "Preliminary study of assessment system for subsurface karst development degree," Xinan Jiaotong Daxue Xuebao/Journal of Southwest Jiaotong University, vol. 53, no. 3, pp. 565-573, 2018.

[23] M. Akhondi and Z. Mohammadi, "Preliminary analysis of spatial development of karst using a geostatistical simulation approach," Bulletin of Engineering Geology and the Environment, vol. 73, no. 4, pp. 1037-1047, 2014.

[24] J. Jouves, S. Viseur, B. Arfib et al., "Speleogenesis, geometry, and topology of caves: a quantitative study of 3D karst conduits," Geomorphology, vol. 298, pp. 86-106, 2017.

[25] X. Wang, T. Wang, Q. Wang, X. Liu, R. Li, and B. J. Liu, "Evaluation of floor water inrush based on fractal theory and an improved analytic hierarchy process," Mine Water and the Environment, vol. 36, no. 1, pp. 87-95, 2017.

[26] X. Wang, W. Zhao, X. Liu et al., "Identification of water inrush source from coalfield based on entropy weight-fuzzy variable set theory," Journal of China Coal Society, vol. 42, no. 9, pp. 2433-2439, 2017.

[27] P. Huang and X. Wang, "Piper-PCA-Fisher recognition model of water inrush source: a case study of the Jiaozuo mining area," Geofluids, vol. 2018, Article ID 9205025, 10 pages, 2018.

[28] Q. Zhang and J. Zhou, "Application of high-density electrical method in analytic hierarchy process to extraction of susceptibility evaluation factor in karst collapse," Chinese Journal of Engineering Geophysics, vol. 15, no. 4, pp. 538-546, 2018. 

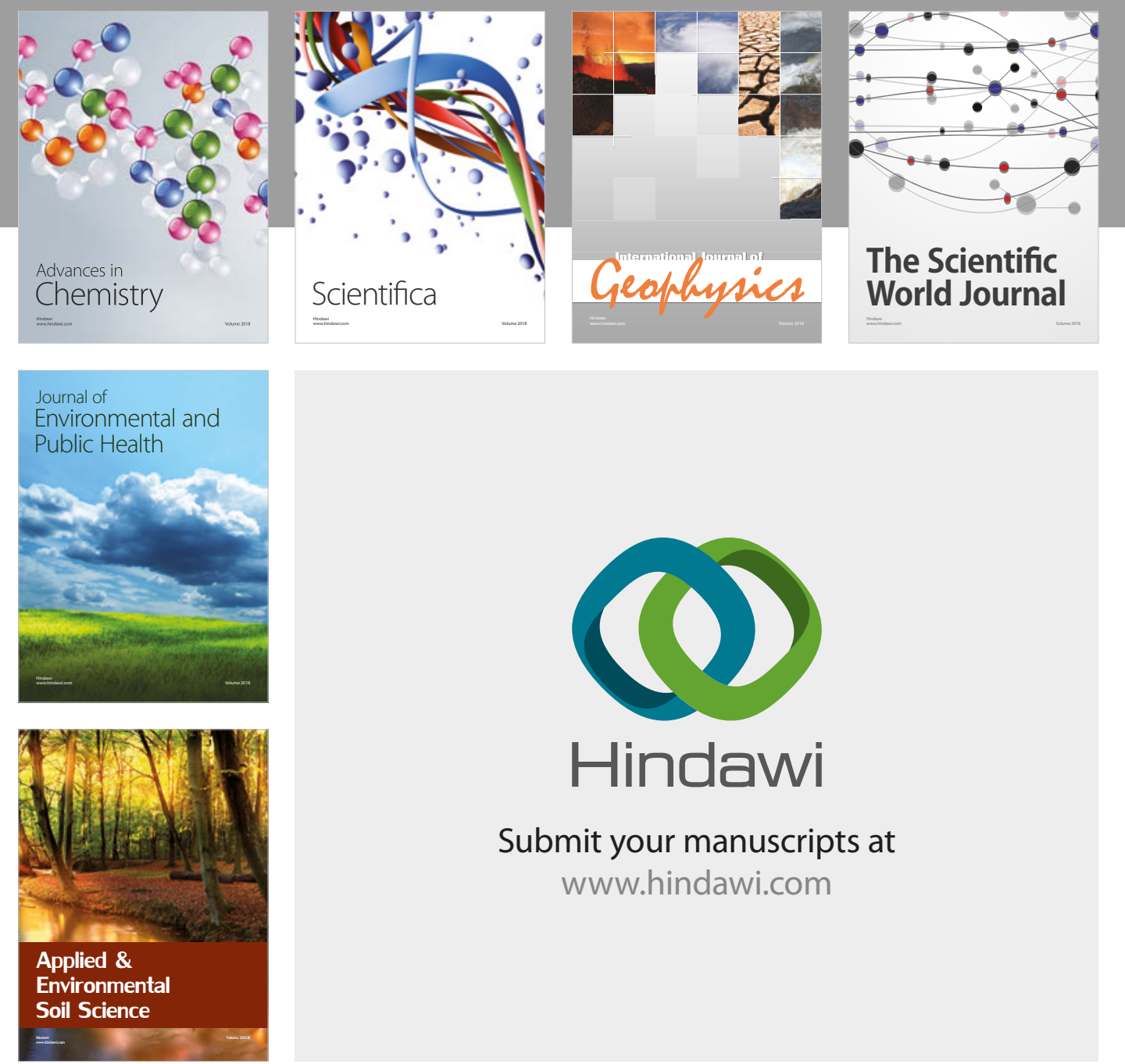

The Scientific

\section{World Journal}
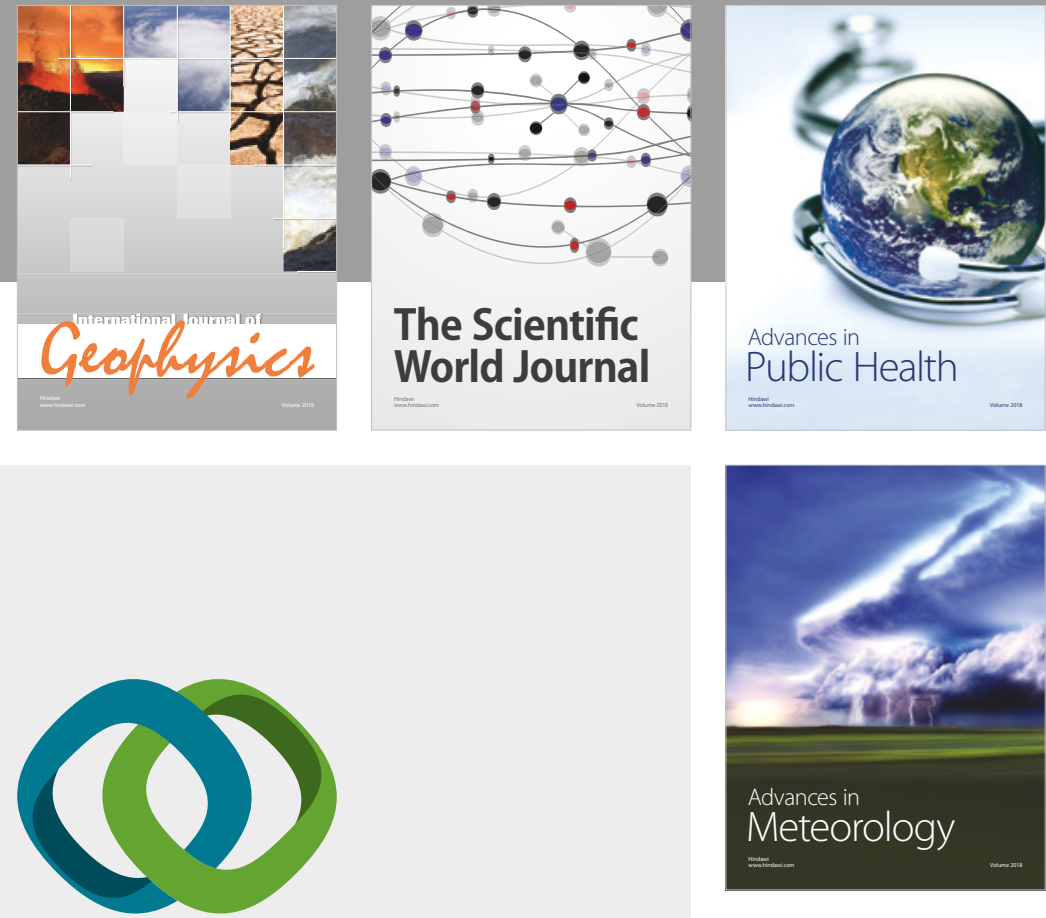

Advan

Public Health

\section{Hindawi}

Submit your manuscripts at

www.hindawi.com
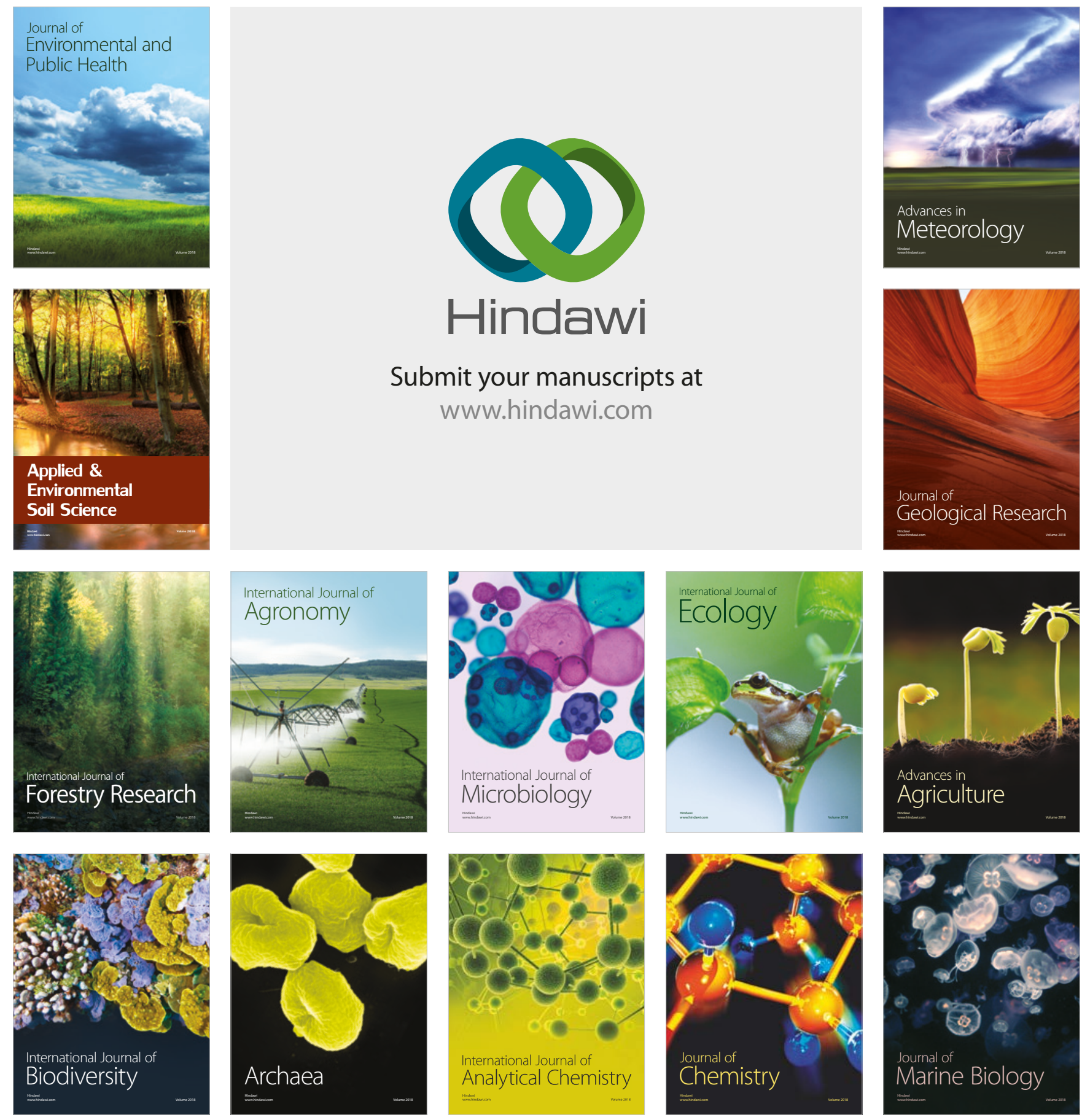